TERMINUS

t. 19 (2017), z. 1 (42), s. 37-59

doi: 10.4467/20843844TE.17.001.7890

www.ejournals.eu/Terminus

Kazimierz Kozica

Zamek Królewski w Warszawie - Muzeum

k.kozica@zamek-krolewski.pl

\title{
Charakterystyka prac kartograficznych Stanisława Pachołowieckiego (1580) ${ }^{1}$
}

\section{Abstract}

\section{A Description of the Cartographic Works of Stanisław Pachołowiecki (1580)}

The paper consists of two parts. The first presents a detailed description of eight maps and the views of cities included in The Atlas of the Principality of Polotsk by Polish cartographer Stanisław Pachołowiecki. They were printed in Rome in the printing house of Giovanni Battista Cavalieri in 1580. The author describes the whole cycle including both states of the plan of the Siege of Polotsk in 1579 and lists all copies known today. The second part discusses the art featured in these maps, particularly the map of the Principality of Polotsk.

Keywords: $16^{\text {th }}$ century cartography, Stanisław Pachołowiecki, Giovanni Battista Cavalieri, Livonian War, Polotsk, Polish-Lithuanian Commonwealth, Stephen Báthory

1 Artykuł powstał $\mathrm{w}$ ramach projektu badawczego Narodowego Centrum Nauki Opus (nr 2014/15/B/HS2/01104) Zwiazki literatury polskiej $i$ kartografii $w X V I-I$ pot. XVII w. 


\section{Stanisław Pachołowiecki, mapa Księstwa Połockiego, 1580}

Tytuł u dołu mapy, po prawej stronie, w prostokątnej podwójnej ramce, jej prawy bok to pojedyncza ramka mapy:

DESCRIPTIO | DVCATVS | POLOCENSIS

W polu ramki z tytułem, wzdłuż jej dolnej krawędzi sygnatura autora mapy:

S. Pacholowic

Poniżej ramki z tytułem sygnatura rytownika:

Joa. Baptista de Cauallerijs Romoe tipis oneis incidebat Anno Domini. i580.

U góry mapy, po lewej stronie, w prostokątnej podwójnej ramce historia Połocka. Transliteracja²:

Polotia priscis temporibus fub annum fcilicet Christi 980, uel ut Rufsi Jupputant á | creato mundo 6488. Suú peculiarem Ducem habuit Rochuoldú Qui á Wlodimirio magno | ob negatá in matrimoniú filiam Rochnedam, (ut annales Mofcorú perhibent) bello uictus | uitam pariter cú duobus filijs ac imperio amisit. Inde Monarchis Rufsioe paruit, quorú $\int u b=\mid$ lata ftirpe ea quoe in Anftrali Rufsia regnabat, Lituanis cum quibusdam ditionibus Rufsicis | concessit. Iagiellone apud Lituànos primú, inde apud Polonos regnante Andreas fŕ. ipsius | Polotioe dńatú arripuerat, ferè cú ipse Iagello Cracouice Coronaretur fed mox missis copijs | cú arce inptēm regis uenit, inde eius dominatus a Magnis Lituanioe Ducibus et Regibus | Polonioe continuatus eft ad annū is63. Quo a Ioanne Bafilij.F.Duce Mofcouice capta eft eiusq ${ }_{3} \mid$ ditionis ager aliquot nouis excitatis arcibus firmatus. Nunc uero demú anno is79 et ipsa | Polotia et arces reliquoe per Seren: Polon: Regé Stephanú partim captoe

2 Zob. G. Franczak, Atlas Księstwa Połockiego Stanisława Pachołowieckiego z 1580 roku - transkrypcja i przekład, „Terminus” 19 (2017), z. 1 (42), s. 66-67. 
partim deletee | uniuerfusq $q_{3}$ ille Ducatus receptus. Ditio hoec ad 30 milliaria in longitudiné in latitudiné uix minus | patet, ac propter ubertaté glebce ac fluminú aliquot, imprimis uero Duno omnium prope Europee $f l u=\mid$ uiox pulcherrimi amoenissimi et ad nauigandú accomódatissimi opportunitaté Rigen isq $_{3}$ portus propinqui $=\mid$ tatè, F Polotia dú à Mosco caperetur diuitijs incolax ipsam Vilnam Juperabat. Regius prefectus Poloce $=\mid n$ sis cú ordine Senatorio Palatini titulum et dignitatem habet. F abundantifsima (to słowo zostało zapomniane przez rytownika $\mathrm{w}$ przedostatnim wierszu)

U góry mapy, po prawej stronie zwieńczony zamkniętą koroną królewską herb Rzeczypospolitej Obojga Narodów (Królestwa Polskiego i Wielkiego Księstwa Litewskiego) z herbem króla Stefana Batorego na polu środkowym (Zęby), poniżej, w prostokątnej podwójnej ramce, ozdobionej u góry i u dołu elementami zwijanymi - dewiza: IN ARMA VICTRICIA | SERENISS STEPHANI | POLONIAE REGIS FELICIS

Pośrodku, przy prawej krawędzi ramki mapy, w prostokątnej podwójnej ramce (jej prawy bok to pojedyncza ramka mapy) dedykacyjny epigram ku czci króla Stefana Batorego, sygnowany przy dolnej ramce przez Tomasza Tretera:

Arcibus inclufus latuit cum milite Mofchus; | Ales eum, STEPHANI Principis, hinc pepulit. | Profilit in campos: fugat hunc mucrone (cruorē| Barbaricum doctus fundere) Regis eques. | Si tentabit aquas; Vncum REX ecce tridentem | Fert. Moschum ex omni fic mala parte premunt.| Protere, Maxime REX, Romani nominis hostem | Quodque facis, CHRISTI jpargere perge Fidé.| THO. TRE Polonus

Autor / rysownik: Stanisław Pachołowiecki

Wydawca: Giovanni Battista Cavalieri

Miedzioryt: $32,5 \mathrm{~cm} \times 42 \mathrm{~cm}$ 


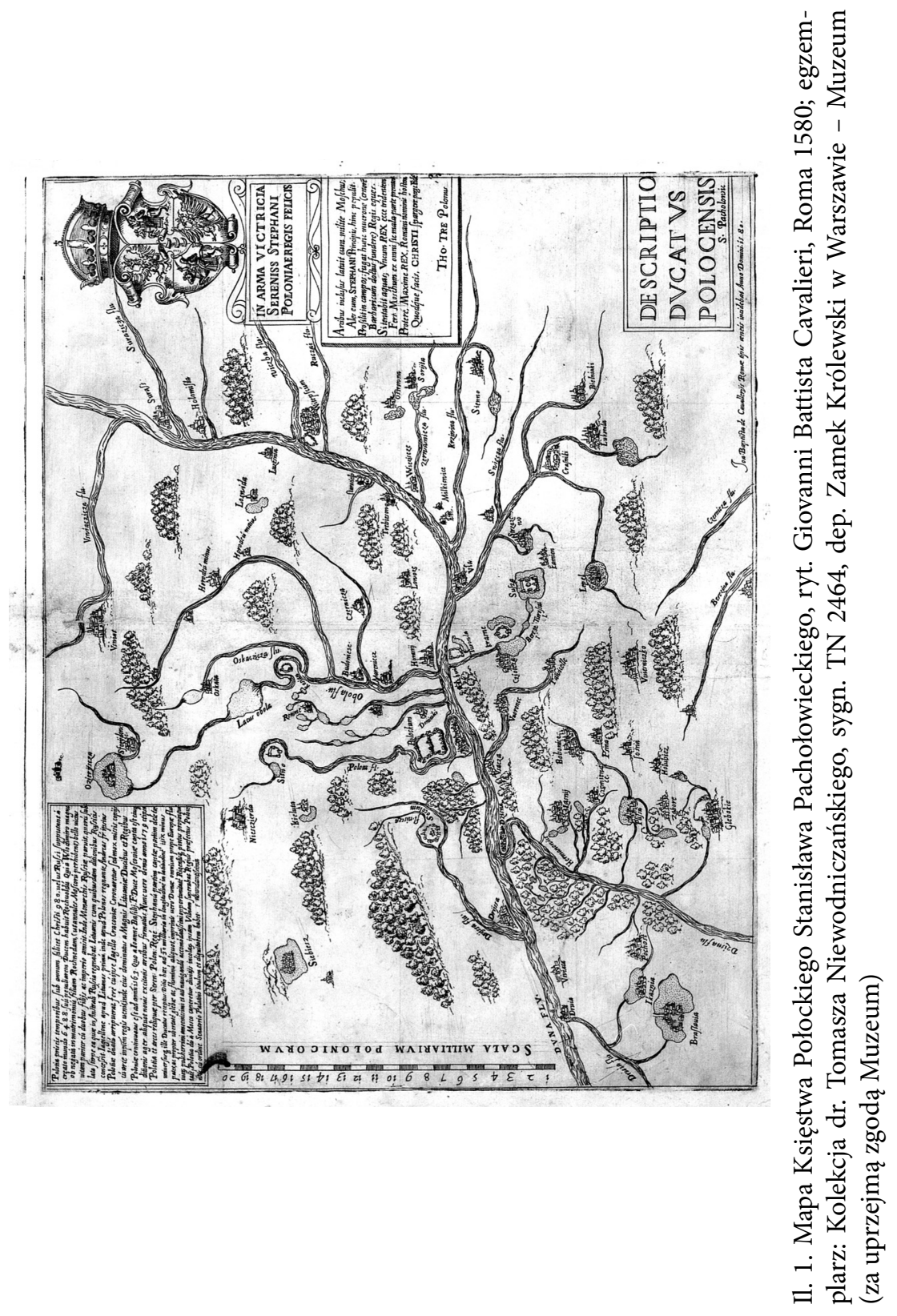




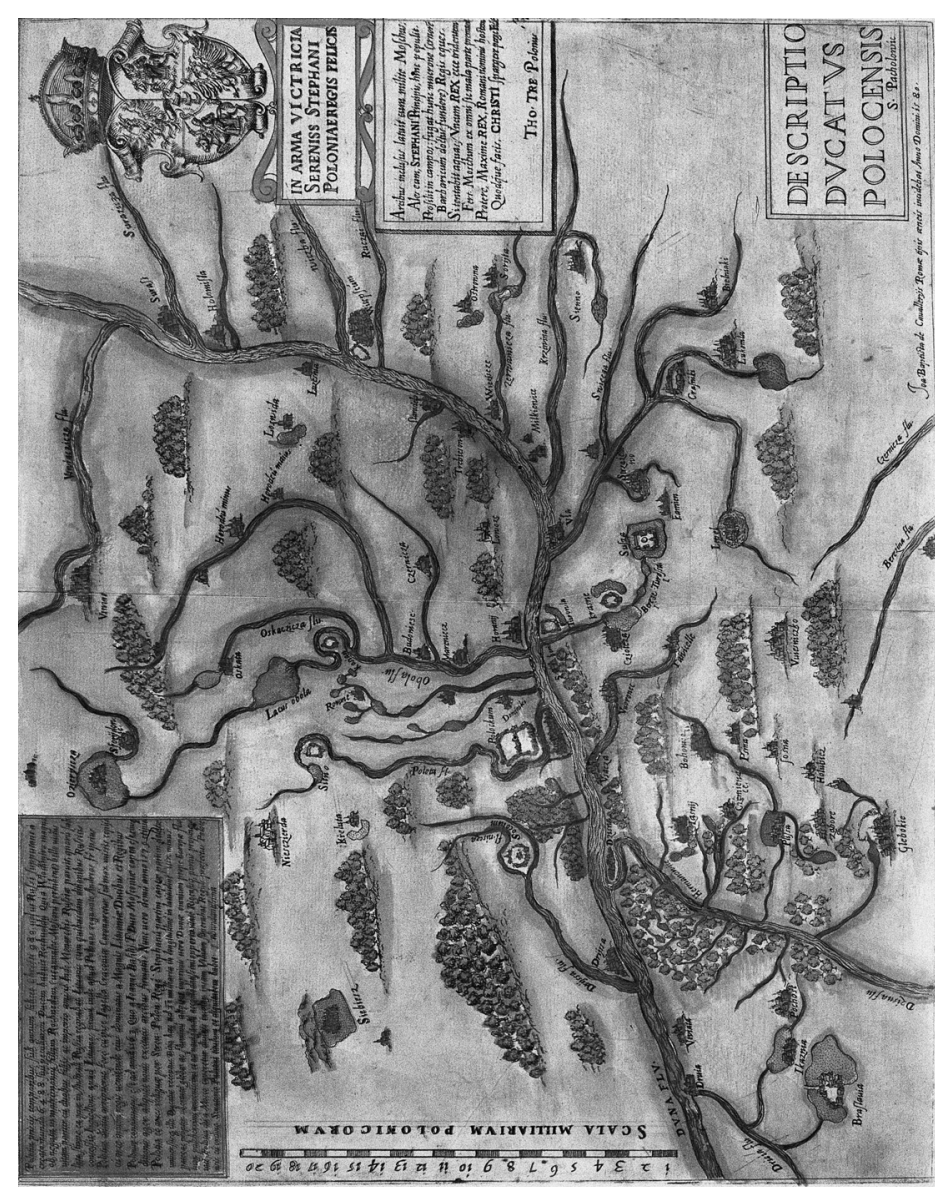

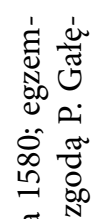

్ㅠ శ్ర 동

ज्ञ

กี

)

ఈ

莺

政

르

胥

의

는

क्ष

争

ช

용

论

ก 0

营造

氜

忢

욜

ن

ن

융 $\frac{\pi}{0}$

需

芆 의

$\frac{2}{2}$

䜦

䒕造.

¿ $\frac{\pi}{\mathrm{N}}$

규 
Wzdłuż lewej ramki mapy opisana skala mapy:

SCALA MILLIARIVM POLONICORVM (20 - 14,9 cm); skala ok. $1: 545000$

Cała mapa otoczona zwykłą pojedynczą ramką, brak siatki kartograficznej i opisanych współrzędnych geograficznych.

Mapa rzadka, znane są tylko cztery jej egzemplarze:

- Kolekcja dr. Tomasza Niewodniczańskiego, dep. Zamek Królewski w Warszawie - Muzeum (sygn. TN 2464, egzemplarz niekolorowany, po konserwacji; il. 1). Egzemplarz ten przypuszczalnie należał do hrabiego Suchodolskiego i stanowi podstawę przedruku Michaiła A. Korkunowa;

- prywatna kolekcja Piotra Gałęzowskiego, Bruksela (egzemplarz kolorowany w epoce, il. 2; wcześniej egzemplarz ten znajdował się także w Kolekcji dr. Tomasza Niewodniczańskiego - zmiana właściciela nastąpiła na drodze wymiany kolekcjonerskiej) $)^{4}$;

- Bibliothèque nationale de France (Département des Estampes et de la Photographie) w Paryżu (kolekcja Lallemant de

3 Zob. J. Niedźwiedź, Atlas Księstwa Połockiego - wprowadzenie, „Terminus” 19 (2017), z. 1 (42), s. 8-10. Pomniejszona reprodukcja: S. Alexandrowicz, Kartografia Wielkiego Księstwa Litewskiego od XV do połowy XVIII wieku, Warszawa 2012, il. 43; A.M. Kobos, Tomasz Niewodniczański (1933-2010) i jego zbiory. In memoriam. Kolekcja Marie-Luise Niewodniczańskiej - kontynuacja, „Prace Komisji Historii Nauki PAU" 11 (2012), s. 169, 170, ryc. 48; G. Schilder, Monumenta Cartographica Neerlandica, vol. 9: Hessel Gerritsz. (1580/81-1632). Master Engraver and Map Maker, Who 'Ruled' the Seas, Houten 2013, s. 211.

4 Pomniejszone reprodukcje: M. Grydzewski, Nad Tamiza o Połocku, „Zwoje. Periodyk Kulturalny" 2003, nr 4 (37), http://www.zwoje-scrolls.com/zwoje37/ text28p.htm (dostęp: 13.09.2017); K. Kozica, J. Pezda, Imago Poloniae. Dawna Rzeczpospolita na mapach, dokumentach i starodrukach $w$ zbiorach Tomasza Niewodniczańskiego. Imago Poloniae. Das Polnisch-Litauische Reich in Karten, Dokumenten und alten Drucken in der Sammlung von Tomasz Niewodniczański, t. 1, Warszawa 2002, s. 55 (poz. H9/2); okładka książki Marka Wrede, Itinerarium króla Stefana Batorego 1576-1586, Warszawa 2010. 
Betz, sygn. 7454, egzemplarz kolorowany w epoce, oznaczony $\mathrm{u}$ dołu pośrodku pola mapy brązową owalną pieczęcią z koroną i inicjałami B.R);

- British Library w Londynie, sygn. ${ }^{*} 33825$ (1), egzemplarz niekolorowany, przycięty do ramki i podklejony, uszkodzony górny lewy narożnik bez szkody dla treści mapy, oznaczony czerwoną pieczęcią o treści: British Museum 16 Jul 1872.

Katalog Imago Poloniae, tom I (2002, poz. H9/2, il. egzemplarz kolorowany mapy, s. 55) wymienia tylko trzy egzemplarze mapy, dwa w ówczesnych zbiorach Tomasza Niewodniczańskiego i egzemplarz paryski. Czwarty obecnie znany egzemplarz tej mapy - londyński został odkryty w 2016 roku przez Jakuba Niedźwiedzia.

\section{Stanisław Pachołowiecki, plan oblężenia Połocka przez wojska Stefana Batorego, 1580}

2.1. Stanisław Pachołowiecki, plan oblężenia Połocka przez wojska Stefana Batorego, stan pierwszy, 1580

Wzdłuż górnej ramki na polu planu:

OBSIDIO ET EXPVGNATIO MVNITISS ARCIS POLOCENSIS PER SERENISS STEPHANVM POLONIAE REGEM

U góry, po prawej stronie, w prostokątnej podwójnej ramce, będącej częścią okuciowego kartusza z elementami zwijanymi i maszkaronem w górnej środkowej jego części, sygnatura rysownika Stanisława Pachołowieckiego:

OBSESSA XI AVG | CAPTA XXIX EIVSD |ANNO. M.D.LXXIX|Delineauit in ipsis Castris. S Pacholowic

Poniżej planu, w prostokątnej ramce będącej częścią całej kompozycji opis historyczny: 
POLOTIA. EX DVABVS ARCIBVS SVPERIORE AC SCLOPETARIORVM OPPIDOQ. ZAPOLOTA CONSTANS ITA SITV LOCI | PROPVGNACVLIS AC INPRIMIS. BOMBARDARVM APPARATV PVLVEREGLOBIS COMMEATVMILITVM PRAESIDIOMV $=\mid$ NITA ET INSTRVCTA VT MERITO NON SOLVM MOSCHOVIAE SED TOTIVS SEPTEMTRIONIS FIRMISSIMVM PROPVGNACVLVM | EXISTIMARETVR OBSESSA. A. SERENISS. POLONIE REGE STEPHANO. XI. AVGVSTI ET MOSCHIS STRENVE DEFENDENTIBVS EREPTA. XXIX. EIVSD. ANNO DOMINI M D LXXIX

Poniżej tego opisu, pośrodku sygnatura wydawcy:

Ioannes Baptista de Cauallerijs Rome tipis æeneis incidebat Anno Domini is 80

Autor / rysownik: Stanisław Pachołowiecki

Wydawca: Giovanni Battista Cavalieri

Miedzioryt, $26 \times 39,5 \mathrm{~cm}$, skala ok. $1: 20000$

Znane są tylko trzy zachowane egzemplarze tej ryciny w jej stanie pierwszym:

- Kolekcja dr. Tomasza Niewodniczańskiego, dep. Zamek Królewski w Warszawie - Muzeum (sygn. TN 2826, egzemplarz niekolorowany, po konserwacji). Egzemplarz ten przypuszczalnie należał do hrabiego Suchodolskiego i stanowi podstawę przedruku Michaiła A. Korkunowa ${ }^{5}$;

- Bibliothèque nationale de France (Département des Estampes et de la Photographie) w Paryżu (kolekcja Lallemant de Betz sygn. 7455, egzemplarz kolorowany w epoce, oznaczony pośrodku pola $\mathrm{z}$ notą historyczną brązową owalną pieczęcią $\mathrm{z}$ koroną i inicjałami B.R);

- British Library w Londynie, sygn. *33825 (2), egzemplarz niekolorowany, przycięty do ramki i podklejony, oznaczony czerwoną pieczęcią o treści: British Museum 16 Jul 1872.

5 Zob. S. Alexandrowicz, Kartografia Wielkiego Księstwa Litewskiego..., s. 60 (il. 42, s. 327); K. Kozica, J. Pezda, Imago Poloniae..., t. I, poz. K9/3. 
2.2. Stanisław Pachołowiecki, plan oblężenia Połocka przez wojska Stefana Batorego, 1580, stan drugi, 1580

Poniżej opisu historycznego, u dołu pośrodku sygnatura wydawcy częściowo tylko wydrukowana w postaci:

(Ioannes Baptista de Cauallerijs Romæ tipis) ceneis incidebat Anno Domini is 80

Wydawca: Giovanni Battista Cavalieri (?)

Dotychczas w literaturze przedmiotu rycina ta znana była tylko w stanie pierwszym, opisanym jak wyżej pod 2.1. Podczas kwerend w 2016 i 2017 roku odkryte zostały przez Jakuba Niedźwiedzia, Grzegorza Franczaka i Karola Łopateckiego trzy egzemplarze stanu drugiego tej ryciny z częściowo usuniętą sygnaturą jej wydawcy - nazwiskiem Giovanniego Battisty Cavalieriego, choć ślady są nadal widoczne. Takie egzemplarze znajdują się w:

- British Library w Londynie, sygn. Maps C.7.e.4.(54.), egzemplarz niekolorowany, przycięty do ramki i podklejony, w zbiorze (jako 54 mapa) z XIX wieku zatytułowanym Towns in Europe. Sixteenth Century, zawierającym 77 planów i widoków miast przedstawiających w większości miasta $\mathrm{z}$ Włoch, a także z Francji, Niderlandów, Niemiec, Hiszpanii i basenu Morza Śródziemnego. Z obszaru Rzeczypospolitej zamieszczono tylko ten widok z lotu ptaka oblężonego Połocka, podobnie jak z obszaru Rosji tylko jeden widok Moskwy;

- Biblioteca Augusta w Perugii (sygn. 2c St serie I 63), egzemplarz niekolorowany;

- Royal Collection Trust (sygn. RCIN 721074), egzemplarz niekolorowany (znamy dokładną historię tego egzemplarza. Znajdował się w bibliotece znanego mecenasa i kolekcjonera

6 Pomniejszona reprodukcja w: J. Niedźwiedź, Źródła, konteksty i okoliczności powstania Ody o zdobyciu Połocka Jana Kochanowskiego, „Terminus” 18 (2016), z. 4 (41), s. 399. 
Cassiana dal Pozzo (1588-1657). Rycinę odziedziczył jego brat Antonio. W 1703 roku jego wnuk sprzedał kolekcję papieżowi Klemensowi XI. Od 1714 roku mapa była własnością kardynała Alessandra Albaniego. Nabył ją król Jerzy III w 1762 roku i od tego czasu jest własnością monarchów brytyjskich?7).

\section{Sześć planów zamków ziemi połockiej zdobytych przez wojska Stefana Batorego, 1580}

(w porządku chronologicznym ich zdobywania)

\subsection{Plan zamku Koziany, 1580}

U góry, pośrodku, na polu planu, w podwójnej ramce na leżącej prostokątnej płycie ozdobionej elementami zwijanymi:

COSSIANVM. ARX.

U dołu, po lewej stronie, na polu planu sygnatura wydawcy:

Joa. Baptista de Cauallerys | Romoe tipis oneis incidebat | Anno Domini. is80.

U dołu, pośrodku, w podwójnej ramce na leżącej prostokątnej płycie ozdobionej elementami okuciowo-zwijanymi nota:

Per Sereniff. Stephanum Polonioe | Regem Moschozy Principi erepta. | et expugnata. Die 23. Iulij. Anno|Domini. is79.

Autor / rysownik: Stanisław Pachołowiecki, Piotr Frankus (?) ${ }^{8}$ Wydawca: Giovanni Battista Cavalieri

7 Szczegóły dotyczące pochodzenia mapy podane są na stronie Royal Collection Trust: https://www.royalcollection.org.uk/collection/721074 (dostęp: 24.08.2017).

8 Na temat autorstwa rysunków, na podstawie których wydano Atlas Księstwa Połockiego zob. K. Łopatecki, Ryciny prezentujące kampanię połocka 1579 roku jako jednolita kompozycja kartograficzna, „Terminus” 19 (2017), z. 1 (42), s. 160-162. 
Miedzioryt, 22,5 × 25,7 cm

Na polu planu opisane dwie rzeki OBOLIA FLVMEN oraz Oskaczicza flumen

\subsection{Plan zamku Krasne, 1580}

U góry, pośrodku, na polu planu, w podwójnej prostokątnej ramce: CRASNA. ARX

U góry, po lewej stronie, na polu planu, sygnatura wydawcy:

Joa. baptista de Cauallerijs incidebat | Romee Anno Domini. is80.

U góry, po prawej stronie, w podwójnej prostokątnej ramce ozdobionej u góry i u dołu elementami okuciowo-zwijanymi, nota:

Per Sereni/simum. Stephanum Polonice | Regem Moschis erepta die XXXI. Mensis | Julij Anno Dńi. M.D.LXXIX.

Autor / rysownik: Stanisław Pachołowiecki, Piotr Frankus (?)

Wydawca: Giovanni Battista Cavalieri

Miedzioryt, 22,5 × 25,7 cm

Na polu planu opisane jezioro CIOTHCZA LACVS

\subsection{Plan zamku Sitno, 1580}

U góry, pośrodku, na polu planu, w podwójnej prostokątnej ramce ozdobionej elementami okuciowo-zwijanymi:

SITNA. ARX.

U góry, po lewej stronie, na polu planu sygnatura wydawcy:

Joa. baptista de Caualleris incidebat Romce is 80

U dołu, po prawej stronie, w podwójnej prostokątnej ramce ozdobionej elementami okuciowo-zwijanymi nota:

Per Sereniffimum Stephanum | Polonice Regem Moschis | erepta; ac deleta Die 4 Aug. | Anno. is79.

Autor / rysownik: Stanisław Pachołowiecki, Piotr Frankus (?) 
Wydawca: Giovanni Battista Cavalieri

Miedzioryt, $22,5 \times 25,7 \mathrm{~cm}$

Na polu planu opisana rzeka POLOTA FLVVIVS oraz jezioro tylko za pomocą słowa lacus

\subsection{Plan zamku Turowla, 1580}

U góry, pośrodku, na polu planu, w podwójnej prostokątnej ramce ozdobionej elementami okuciowo-zwijanymi:

TVROVLIA. ARX

U dołu, po prawej stronie, w podwójnej prostokątnej ramce ozdobionej elementami okuciowo-zwijanymi, nota:

Per Jereniss. Stephanum Polonioe | Regem, Moschis erepta Die 4 |Septemb. Anno. is79.

Poniżej tej ramki z notą, na polu planu, sygnatura wydawcy:

Jo. baptista de Cauallerijs incidebat | Romoe is80.

Autor / rysownik: Stanisław Pachołowiecki, Piotr Frankus (?)

Wydawca: Giovanni Battista Cavalieri

Miedzioryt, $22,5 \times 25,7 \mathrm{~cm}$

Na polu planu opisane dwie rzeki DHVNA FLVVIVS i TVROWKA. $F L V$. oraz jezioro tylko za pomocą słowa $L A C V S$

\subsection{Plan zamku Sokół, 1580}

U góry, pośrodku, na polu planu, w podwójnej prostokątnej ramce: SOCOLVM. ARX.

U dołu, po prawej stronie, w podwójnej prostokątnej ramce nota:

Per Sereni. Stephanum Polonioe Re |gem, coesis multis Protorianis Moschi| militibus, expugnata et deleta dié ii. |Septemb. Anno. is79

$\mathrm{U}$ dołu, pośrodku, na polu planu sygnatura wydawcy:

Ioa baptista de Cauallerijs incidebat Romoe is80. 
Autor / rysownik: Stanisław Pachołowiecki, Piotr Frankus (?)

Wydawca: Giovanni Battista Cavalieri

Miedzioryt, $22,5 \times 25,7 \mathrm{~cm}$


oraz FOSSA

\subsection{Plan zamku Susza, 1580}

U góry, pośrodku na polu planu, w podwójnej prostokątnej ramce: SVSSA. ARX.

U góry, po lewej stronie, w podwójnej pochyłej prostokątnej ramce (jej lewy bok to pojedyncza ramka planu) ozdobionej elementami okuciowo-zwijanymi, nota:

Munitissimo loco posita, et per Sere=| niff. Stephanum Polonia Regem $\mid$ Moschis erepta Die 6. Octob $\mid$ Anno D. is79

Poniżej tej ramki z notą, na polu planu sygnatura wydawcy:

Joa. Baptista de Cauallerys | Romoe tipis oneis incidebat | Anno. Domini. is80.

Autor / rysownik: Stanisław Pachołowiecki, Piotr Frankus (?)

Wydawca: Giovanni Battista Cavalieri

Miedzioryt, $22,5 \times 25,7 \mathrm{~cm}$

Na polu planu opisane jezioro SVSSA LACVS

Jest to zespół sześciu planów przedstawiających zamki wzniesione na ziemi połockiej przez wojska cara Iwana IV Groźnego po zdobyciu Połocka w 1563 roku. Zamki te zostały zdobyte przez wojska polskie i litewskie króla Stefana Batorego podczas kampanii wojennej w 1579 roku. O planie oblężonego Połocka i sześciu planach zdobytych zamków na ziemi połockiej szerzej pisze Stanisław Alexandrowicz' ${ }^{9}$.

9 Zob. S. Alexandrowicz, Kartografia Wielkiego Księstwa Litewskiego..., s. 60, przypis 122 (tam podana literatura na ich temat), s. 172-174, i przypis 367 na s. 172 (tam także podana literatura). 
Komplety tych sześciu rycin zamków znajdują się w następujących zbiorach:

- Kolekcja dr. Tomasza Niewodniczańskiego, dep. Zamek Królewski w Warszawie (egzemplarze niekolorowane, luźne arkusze, po konserwacji). Egzemplarze te przypuszczalnie należały do hrabiego Suchodolskiego i stanowią podstawę przedruku Michaiła A. Korkunowa;

- prywatna kolekcja Piotra Gałęzowskiego, Bruksela (egzemplarze niekolorowane, sklejone po dwa; proweniencja: nabyte w handlu antykwarycznym);

- Bibliothèque nationale de France (Département des Estampes et de la Photographie) w Paryżu (kolekcja Lallemant de Betz sygn. 7456-7461, egzemplarze kolorowane w epoce, sklejone po dwa, każdy egzemplarz oznaczony u dołu, pośrodku pola planu brązową owalną pieczęcią z koroną i inicjałami $B . R)^{10}$;

- British Library w Londynie, sygn. Maps 34139.(1.), egzemplarze niekolorowane, naklejone na karton po trzy w kolejności alfabetycznej i oznaczone czerwoną pieczęcią o treści: British Museum 16 Jul 1872.

Mapa Księstwa Połockiego Stanisława Pachołowieckiego z 1580 roku należy do rzadszych map w historii kartografii polskiej. Jest to pierwsza drukowana szczegółowa mapa przedstawiająca tę część ziem Wielkiego Księstwa Litewskiego. Jej powstanie należy widzieć w kontekście rozwoju rodzimej produkcji kartograficznej odnoszącej się do północnych ziem Wielkiego Księstwa Litewskiego w czasie trzech kampanii króla Stefana Batorego w latach 1579-1582, a konkretnie należy łączyć je z działaniami wojennymi kampanii połockiej w 1579 roku $^{11}$. Spośród licznego zapewne zasobu materiałów karto-

10 Zob. A. Flandrin, Inventaire de la collection Lallemant de Betz, Paris 1903, s. 342, poz. 7456-7461.

11 Zob. K. Łopatecki, Okoliczności powstania i przydatność wojskowa mapy Descriptio Ducatus Polocensis Stanisława Pachołowieckiego (1580), „Terminus” 19 (2017), z. 1 (42), s. 158-159. 
graficznych - głównie rękopiśmiennych - służących do prowadzenia działań wojennych podczas tych wypraw tylko ta mapa Księstwa Połockiego Stanisława Pachołowieckiego została wydana drukiem w Rzymie w 1580 roku $^{12}$.

Autorem mapy był Stanisław Pachołowiecki, o którym większość zachowanych informacji pochodzi z przywileju nobilitacyjnego $^{13}$. Pachołowiecki, pierwotnie Pachołowic, był sekretarzem kancelarii koronnej króla Stefana Batorego i kartografem, działał w drugiej połowie XVI wieku. Brak dokładnych dat jego życia, podobnie jak brak informacji o jego pochodzeniu. Wczesną młodość spędził w służbie na dworach magnackich. W latach 1563-1566 był w służbie królowej Katarzyny, trzeciej żony Zygmunta Augusta. Następnie pracował w kancelarii skarbowej i kancelarii koronnej. Brał udział w wyprawach wojennych: wiosną 1572 roku do Mołdawii pod dowództwem wojewody podolskiego Mikołaja Mieleckiego, a w latach 1579-1582 w trzech kolejnych kampaniach króla Stefana Batorego - połockiej, wielkołuckiej i pskowskiej. W kampaniach tych obok obowiązków sekretarza kancelarii koronnej pełnił funkcję kartografa. Jego działalność była wysoko ceniona przez króla. Podczas trzeciej kampanii Pachołowiecki odznaczył się, biorąc ochotniczo udział w oblężeniu Pskowa i w szturmie jego fortyfikacji 8 września 1581 roku. Jako pierwszy, obok rotmistrzów Łukasza Sernego i Wawrzyńca Wybranowskiego, wdarł się na uszkodzone przez artylerię polską mury i basztę, wypierając z niej obrońców. Za okazane męstwo i zasługi wojenne został nobilitowany przez króla Stefana przywilejem wystawionym w obozie pod Pskowem 10 września 1581 roku, z nadaniem herbu Pskowczyk. Zarówno godło, jak i klejnoty herbu podkreślają protekcję króla i Jana Zamoyskiego, który darzył kartografa wielkimi względami. W grud-

12 Ibidem, s. 160, 162-163.

13 Biogram Pachołowieckiego podaję za: S. Alexandrowicz, Pachołowiecki Stanisław, w: Polski słownik biograficzny, t. 24, Kraków 1979, s. 761-762. 
niu 1581 roku Pachołowiecki odjechał z obozu do Rygi. W następnych latach pozostawał w służbie kancelarii. Ostatnia potwierdzona wiadomość o jego życiu to rola świadka w dokumencie lokacyjnym Szarogrodu (Zamość, 28 października 1585 roku). Brak wiadomości o stosunkach rodzinnych Pachołowieckiego. Nie zdołano ustalić pełnej listy jego prac kartograficznych.

Mapa Księstwa Połockiego została najprawdopodobniej narysowana przez Pachołowieckiego w pierwszej połowie 1579 roku przed rozpoczęciem kampanii ${ }^{14}$. Już w trakcie oblężenia powstał rysunek planu oblężenia Połocka (OBSIDIO ET EXPVGNATIO MVNITISS ARCIS POLOCENSIS PER SERENISS STEPHANVM POLONIAE REGEM). Następnie zostały wyrytowane w 1580 roku w Rzymie i opublikowane przez tamtejszego znanego rytownika i wydawcę Giovanniego Battistę Cavalieriego ${ }^{15}$. Mapę Księstwa Połockiego i plan oblężenia Połocka ${ }^{16}$ opublikowano w 1580 roku wraz z ry-

14 Zob. K. Łopatecki, Okoliczności powstania i przydatność wojskowa mapy..., s. 79, 93-102.

15 Giovanni Battista Cavalieri (Cavalieri, Cavalleri, Cavallieri, de Cavalleriis, De Cavalieri, De Cavalleri, Cavalleris, 1525-1601) - włoski rytownik działający w Rzymie, słynny za sprawą monumentalnego i wielokrotnie wznawianego dzieła Antiquarum statuarum Urbis Romae l. quatuor (ok. 1561-1594). Jako kartograf znany głównie z wykonania dwóch map: Księstwa Połockiego (Descriptio Ducatus Polocensis) w 1580 roku i okolic zamku Dieppe we Francji nad kanałem La Manche (Descritione della Terra, et Castello di Dieppa, assediata dal Sigr. Duca d'Humena) w 1589 roku. Zob. Tooley's Dictionary of Mapmakers, revised edition, A-D, ed. by J. French, Tring 1999, s. 245; G. Franczak, Rzymski łącznik. Giovanni Battista Cavalieri (1525-1601), rytownik Hozjusza i Tretera (w przygotowaniu); J. Niedźwiedź, Polska szesnastowieczna propaganda wojenna w działaniu: przypadek Atlasu Księstwa Połockiego (1580), „Terminus” 19 (2017), z. 3 (44), s. 477-510.

16 Pachołowiecki (lub Piotr Frankus) sporządził też inny rysunek przedstawiający oblężenie Połocka niż ten stanowiący podstawę rzymskiej grafiki. Kopia tego planu wykonana przez Pawła Zumthorna znajduje się dzisiaj w zbiorach Staatsarchiv w Dreźnie (sygn. R. Schr. VII Fach 90 nr 17a). Jego negatyw przechowywany jest w IS PAN w Warszawie. Wykonany piórkiem rysunek i kolorowany akwarelą przedstawia moment szturmu Połocka (29 sierpnia 1579 roku) wraz ze szczegółowym przedstawieniem fortyfikacji i zabudowy wewnętrznej obu zamków - górnego 
cinami przedstawiającymi sześć planów zdobytych zamków ziemi połockiej przez wojska Stefana Batorego (są to w porządku alfabetycznym: Kozian, Krasne, Sitno, Sokół, Susza i Turowla). Choć autorstwo tych planów za K. Buczkiem ${ }^{17}$ przypisywane jest inżynierowi i geometrze królewskiemu Włochowi Piotrowi Frankusowi $^{18}$, to jak pisze S. Alexandrowicz, „nie można wykluczyć, może w stosunku do części z nich, autorstwa Pachołowieckiego"19. Jeżeli chodzi o nazwisko rytownika, który wykonał te wszystkie prace, to Stanisław Alexandrowicz błędnie przypisał ich wykonanie przebywającemu wtedy w Rzymie Tomaszowi Treterowi (1547-1610) ${ }^{20}$. Ten ostatni autor podaje już informację o oryginalnych egzemplarzach rycin planów zamków ziemi połockiej przechowywanych w Paryżu ${ }^{21}$.

Na znaczenie map Stanisława Pachołowieckiego jako pierwszy zwrócił uwagę Michaił A. Korkunow. Wydał je w 1837 roku w Petersburgu, a w 1840 roku ukazał się polski przekład tej publikacji ${ }^{22}$.

i strzeleckiego - oraz obozów i stanowisk wojsk Batorego i miejscowej topografii. Zob. K. Łopatecki, Ocena wiarygodności źródeł kartograficznych prezentujących oblężenie Połocka z 1579 roku, „Terminus” 19 (2017), z. 4 (45), s. 759-795.

17 Zob. K. Buczek, Kartografia polska w czasach Stefana Batorego, „Wiadomości Służby Geograficznej" 7 (1933), z. 2, s. 81-82; idem, Dorobek kartograficzny wojen Stefana Batorego, „Wiadomości Służby Geograficznej” 8 (1934), z. 3, s. 4.

18 Zob. K. Łopatecki, Ryciny prezentujące kampanię połocka..., s. 161.

19 S. Alexandrowicz, Pachołowiecki Stanisław..., s. 761; idem, Kartografia Wielkiego Księstwa Litewskiego..., s. 172.

20 Zob. S. Alexandrowicz, Kartografia Wielkiego Księstwa Litewskiego..., s. 172, przyp. 367, s. 173; T. Chrzanowski, Działalność artystyczna Tomasza Tretera, Warszawa 1984, s. 19. Tę atrybucję podważają K. Łopatecki i G. Franczak, zob. K. Łopatecki, Ryciny prezentujące kampanię polocka..., s. 164; G. Franczak, Filologia mapy. Badanie dawnej kartografii metoda krytyki tekstu na przykładzie toponimii mapy Księstwa Połockiego S. Pachołowieckiego z 1580 roku, „Terminus” 19 (2017), z. 1 (42), s. 204.

${ }_{21}$ Zob. T. Chrzanowski, Działalność artystyczna..., s. 37, przyp. 60.

22 Zob. M.A. Коркунов, Карта военных действий между русскими и поляками в 1579 г. и тогдашние планы г. Полоцка и его окрестностей, „Журнал Министерства народного просвещения" 15 (1837), № 8, s. 235-249. Polskie 
Pod koniec XIX wieku w Archiwum Jana Zamoyskiego przedrukowano mapy $\mathrm{z}$ edycji Korkunowa w wielkości oryginału (443 $\times$ $333 \mathrm{~mm})^{23}$. Spośród Polaków o mapie Księstwa Połockiego pisał Bolesław Olszewicz w Kartografii polskiej XV i XVI wieku (1931), podając także starszą literaturę o niej, jak i o jej autorze (z uzupełnieniami w Kartografii polskiej XVII w. $)^{24}$. Szczegółowo omówił te mapy i plany Buczek w swej pracy Kartografia polska w czasach Stefana Batorego ${ }^{25}$, podał także silnie pomniejszoną reprodukcję mapy Księstwa Połockiego na tabeli VIII (opisanej błędnie jako tabela III). Buczek ponownie pisał o tej mapie w swej Historii kartografii polskiej ${ }^{26}$. Omówił ją Stanisław Alexandrowicz w Kartografii Wielkiego Księstwa Litewskiego ${ }^{27}$. O samym autorze mapy - Stanisławie Pachołowieckim - powstał biogram do Polskiego słownika biograficznego pióra Stanisława Alexandrowicza ${ }^{28}$. W 1998 roku nakładem wydawnictwa Uitgeverij Canaletto, specjalizującego się

tłumaczenie wyszło trzy lata później we Wrocławiu nakładem Zygmunta Schlettera w drukarni M. Frydlendera: [M.A. Korkunow], Karta operacyj wojennych $w$ wyprawie Polaków przeciw Rossyjanom w roku 1579 i plany ówczesne miasta Połocka z przyległemi twierdzami. Wyjątek z Dziennika Ministerstwa Oświecenia narodowego r. 1837, Sierpień, numer VIII, Wrocław 1840. Poza 15 stronami tekstu zamieszczono reprodukcje mapy Księstwa Połockiego, widok z lotu ptaka oblężonego Połocka w 1579 roku i sześć planów okolicznych twierdz. Odbito je z płyt litograficznych przygotowanych do wspomnianej wcześniejszej pracy M. Korkunowa z 1837 roku (zob.: https://polona.pl/item/42216769/1/). Zob. J. Niedźwiedź, Atlas Księstwa Połockiego - wprowadzenie..., s. 8-10.

${ }_{23}$ Zob. Archiwum Jana Zamoyskiego, kanclerza i hetmana wielkiego koronnego, t. 2: 1580-1582, wyd. J. Siemieński, Warszawa 1909, s. 422-423.

${ }^{24}$ B. Olszewicz, Kartografia polska XV i XVI wieku, „Polski Przegląd Kartograficzny" 4 (1929/1930), nr 31, s. 163-164; idem, Kartografia polska XVII wieku, „Polski Przegląd Kartograficzny” 5 (1931/1932), nr 36, s. 136.

25 Zob. K. Buczek, Kartografia polska w czasach Stefana Batorego, s. 80-82.

26 Zob. K. Buczek, Dzieje kartografii polskiej od XV do XVIII wieku. Zarys analityczno-syntetyczny, Wrocław 1963, s. 45-47.

27 Zob. S. Alexandrowicz, Kartografia Wielkiego Księstwa Litewskiego..., s. $60-61$.

${ }_{28}$ Zob. S. Alexandrowicz, Pachołowiecki Stanisław..., s. 761-762. 
między innymi $\mathrm{w}$ reprintach map, planowano wydanie reprintu mapy Księstwa Połockiego. Nie ukazał się, ale notuje go jednak internetowa Open Libarary ${ }^{29}$.

Zarówno w swoim opracowaniu z 1933, jak i w pracy z 1963 roku jako ilustrację mapy Księstwa Połockiego Buczek zamieścił jej pomniejszenie na podstawie znanego mu wtedy faksymile z pracy Michaiła A. Korkunowa z 1837 roku. Pisał przy tej okazji: „nie wiadomo bowiem, czy jakaś biblioteka posiada oryginalną odbitkę tej mapy"30.

Ocena mapy Księstwa Połockiego Stanisława Pachołowieckiego pomnika polskiej kartografii wojskowej - dokonana przez Buczka na podstawie faksymile z około 1837 roku nie jest najlepsza. Historyk stawia zarzut, że mapa jest

fatalnie zorientowana i wykonana bardzo brzydko, tak że wygląda raczej na szkic terenowy, którego autor nie znał przy tym z autopsji całego obszaru, a tylko jego południową część. Jak na swoją skalę mapa posiada bardzo szczupłą treść, przy czym rzeka Dźwina płynie na niej po ujście Krzywicy $\mathrm{ku}$ południowi, zamiast ku południowemu zachodowi, a dalej ku południowemu zachodowi, zamiast ku północnemu zachodowi ${ }^{31}$.

Skalę mapy Buczek określił na w przybliżeniu $1: 700$ 000, czyli na mniejszą niż faktycznie.

Nieco lepiej mapę Księstwa Połockiego ocenił Alexandrowicz ${ }^{32}$. Średnią skalę mapy obliczył na 1:545 000, co daje podanej na mapie mili polskiej około 5,6 km. Ustalenia te sprostował Karol Łopatecki,

29 Zob. Descriptio ducatus Polocensis. Reprint of the 1580, Alphen aan den Rijn: Uitgeverij Canaletto, 1998 (Series Cartographica Rarissima). Wznowienia tego oczywiście nie notują katalogi biblioteczne. https://openlibrary.org/works/OL12525 030W/Descriptio_ducatus_Polocensis (dostęp: 24.08.2017).

30 K. Buczek, Dzieje kartografii polskiej..., s. 40, przyp. 120.

31 Ibidem, s. 40.

32 Zob. S. Alexandrowicz, Kartografia Wielkiego Księstwa Litewskiego..., s. 60-61. 
który obliczył, że długość mili wynosi $4,99 \mathrm{~km}^{33}$. Buczek orientację mapy określił jako północną, natomiast Alexandrowicz, po konfrontacji sieci miejscowości i sieci rzecznej ze współczesną mapą topograficzną, jako północno-wschodnio-wschodnią. Zasięg terytorialny mapy według Alexandrowicza na linii północ-południe to $165 \mathrm{~km}$ (pomiędzy najdalej na północ leżącym Siebieżem i leżącymi na południu miejscowościami Łukomlą i Bielniakami), a na linii wschódzachód $230 \mathrm{~km}$ (pomiędzy leżącym na wschodzie Surażem i leżącym na zachodzie Brasławiem), co daje około 38 tys. $\mathrm{km}^{2}$ obszaru ujętego na mapie Pachołowieckiego. $Z$ tego obszaru na mapie przedstawiono za pomocą sygnatur 67 miejscowości opisanych nazwami ${ }^{34}$ oraz siedem nieopisanych nazwami, zaznaczonych samymi tylko sygnaturami. Linie siatki zniekształceń wykazują liczne deformacje. Pomimo tych niedociągnięć mapa Księstwa Połockiego spełniała swoje zadanie i zapewniała ogólną orientację w dość skomplikowanym obrazie systemu wodnego i sieci osadniczej terenów na niej przedstawionych, a będących obszarem teatru wojny w 1579 roku $^{35}$.

Jak słusznie zauważa Alexandrowicz, mapa Księstwa Połockiego Stanisława Pachołowieckiego z 1580 roku zasługuje na uwagę jako pierwsze opublikowane drukiem szczegółowe kartograficzne ujęcie części ziem Wielkiego Księstwa Litewskiego, jednak metoda opracowania i wykonania mapy oraz poprawność ukazanego na mapie obrazu pozostawia wiele do życzenia ${ }^{36}$. Z tych powodów ogólna ocena mapy musi być dość krytyczna. Niemniej mapa ta odegrała znaczącą rolę w kształtowaniu obrazu kartograficznego tej części ziem Wielkiego Księstwa Litewskiego w kartografii XVI i początku XVII

33 Zob. K. Łopatecki, Okoliczności powstania i przydatność wojskowa mapy..., s. 104.

34 Zob. G. Franczak, Filologia mapy..., s. 225-252. Alexandrowicz podaje błędnie 69 toponimów.

35 Zob. K. Łopatecki, Okoliczności powstania i przydatność wojskowa mapy..., s. $117-118$.

36 Zob. S. Alexandrowicz, Kartografia Wielkiego Księstwa Litewskiego..., s. 61. 
wieku ${ }^{37}$. Była ona bowiem wykorzystana bezpośrednio lub pośrednio przez innych kartografów, autorów innych map - Macieja Strubicza (w jego mapach rękopiśmiennych 1579 roku i w ich późniejszych redakcjach, z których zachowała się tylko mapa teatru wojny o Inflanty, wydrukowana w 1589 roku w Kolonii jako mapa Litwy w Polonii M. Kromera), Gerarda Mercatora (jego mapa Lithuania opublikowana pośmiertnie w 1595 roku) czy wreszcie przez autora lub grupę twórców mapy Radziwiłłowskiej Wielkiego Księstwa Litewskiego (zwanej także mapą Tomasza Makowskiego, 1613/1631). Z kolei na pracach tych ostatnich opierali się następnie liczni zachodni kartografowie i wydawcy ${ }^{38}$. Na zakończenie warto jeszcze wspomnieć, że prace kartograficzne i rysunki zamków wykonane przez Pachołowieckiego były także pomocne w opracowaniu odpowiednich części dzieła Reinholda Heidensteina De bello Moscovitico commentariorum libri sex (Kraków 1584).

\section{Bibliografia}

Коркунов М.А., Карта военных действий между русскими и поляками в 1579 г. и тогдашние планы г. Полоцка и его окрестностей, „Журнал Министерства народного просвещения" 15 (1837), №. 8, s. 235-249.

Alexandrowicz S., Kartografia Wielkiego Księstwa Litewskiego od XV do połowy XVIII wieku, Warszawa 2012.

Alexandrowicz S., Pachołowiecki Stanisław, w: Polski słownik biograficzny, t. 24, Kraków 1979, s. 761-762.

Archiwum Jana Zamoyskiego, kanclerza i hetmana wielkiego koronnego, t. 2: 15801582, wyd. J. Siemieński, Warszawa 1909.

Buczek K., Kartografia polska w czasach Stefana Batorego, „Wiadomości Służby Geograficznej" 7 (1933), z. 2, s. 69-121.

Buczek K., Dorobek kartograficzny wojen Stefana Batorego, „Wiadomości Służby Geograficznej" 8 (1934), z. 3, s. 3-15.

37 Zob. G. Franczak, Filologia mapy..., s. 213.

38 Zob. ibidem, s. 213-214, 218. 
Buczek K., Dzieje kartografii polskiej od XV do XVIII wieku. Zarys analityczno-syntetyczny, Wrocław 1963.

Chrzanowski T., Działalność artystyczna Tomasza Tretera, Warszawa 1984.

Flandrin A., Inventaire de la collection Lallemant de Betz, Paris 1903.

Franczak G., Atlas Księstwa Połockiego Stanisława Pachołowieckiego z 1580 roku transkrypcja i przekład, „Terminus” 19 (2017), z. 1 (42), s. 61-74.

Franczak G., Filologia mapy. Badanie dawnej kartografii metoda krytyki tekstu na przykładzie toponimii mapy Księstwa Połockiego S. Pachołowieckiego $z 1580$ roku, „Terminus” 19 (2017), z. 1 (42), s. 193-252.

Franczak G., Rzymski łącznik: Giovanni Battista Cavalieri (1525-1601), rytownik Hozjusza i Tretera (w przygotowaniu).

Grydzewski M., Nad Tamiza o Połocku, „Zwoje. Periodyk Kulturalny” 2003, nr 4 (37), http://www.zwoje-scrolls.com/zwoje37/text28p.htm (dostęp: 13.09.2017).

Kobos A.M., Tomasz Niewodniczański (1933-2010) i jego zbiory. In memoriam. Kolekcja Marie-Luise Niewodniczańskiej - kontynuacja, „Prace Komisji Historii Nauki PAU” 11 (2012), s. 149-197.

Korkunow M.A., Karta operacyj wojennych w wyprawie Polaków przeciw Rossyjanom w roku 1579 i plany ówczesne miasta Połocka z przyległemi twierdzami. Wyjątek z Dziennika Ministerstwa Oświecenia Narodowego r. 1837, Sierpień, numer VIII, Wrocław 1840.

Kozica K., Pezda J., Imago Poloniae. Dawna Rzeczpospolita na mapach, dokumentach i starodrukach w zbiorach Tomasza Niewodniczańskiego, t. I, Warszawa 2002.

Łopatecki K., Ocena wiarygodności źródeł kartograficznych prezentujących oblężenie Połocka z 1579 roku, „Terminus” 19 (2017), z. 4 (45), s. 759-795.

Łopatecki K., Okoliczności powstania i przydatność wojskowa mapy Descriptio Ducatus Polocensis Stanisława Pachołowieckiego (1580), „Terminus” 19 (2017), z. 1 (42), s. 75-126.

Łopatecki K., Ryciny prezentujące kampanię połockq 1579 roku jako jednolita kompozycja kartograficzna, „Terminus” 19 (2017), z. 1 (42), s. 157-191.

Niedźwiedź J., Atlas Księstwa Połockiego Stanisława Pachołowieckiego (1580): propaganda, genologia i tworzenie wiedzy geograficznej, „Terminus” 19 (2017), z. 1 (42), s. 127-155.

Niedźwiedź J., Polska szesnastowieczna propaganda wojenna $w$ działaniu: przypadek Atlasu Księstwa Połockiego (1580), „Terminus” 19 (2017), z. 3 (44), s. 477-510.

Niedźwiedź J., Atlas Księstwa Połockiego - wprowadzenie, „Terminus” 19 (2017), z. 1 (42), s. 1-18.

Niedźwiedź J., Źródła, konteksty i okoliczności powstania Ody o zdobyciu Połocka Jana Kochanowskiego, „Terminus” 18 (2016), z. 4 (41), s. 359-400.

Olszewicz B., Kartografia polska XV i XVI wieku, „Polski Przegląd Kartograficzny” 4 (1929/1930), nr 31, s. 147-168.

Olszewicz B., Kartografia polska XVII wieku, „Polski Przegląd Kartograficzny” 5 (1931/1932), nr 36, s. 109-138. 
Schilder G., Monumenta Cartographica Neerlandica, vol. 9: Hessel Gerritsz. (1580/81-1632). Master Engraver and Map Maker, Who 'Ruled' the Seas, Houten 2013.

Tooley's Dictionary of Mapmakers, revised edition, A-D, ed. by J. French, Tring 1999. Tooley's Dictionary of Mapmakers, revised edition, K-P, ed. by V. Scott, Riverside 2003. 